\title{
Risk assessment of debris flow in Yushu seismic area in China: a perspective for the reconstruction
}

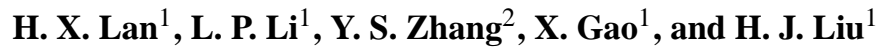 \\ ${ }^{1}$ State Key Laboratory of Resources and Environmental Information System, Institute of Geographic Sciences and Natural \\ Resources Research, Chinese Academy of Sciences, Beijing 100101, China \\ ${ }^{2}$ Institute of Geomechanics, Chinese Academy of Geological Sciences, Beijing 100081, China
}

Correspondence to: H. X. Lan (lanhx@igsnrr.ac.cn)

Received: 31 October 2011 - Published in Nat. Hazards Earth Syst. Sci. Discuss.: -

Revised: 11 October 2013 - Accepted: 15 October 2013 - Published: 22 November 2013

\begin{abstract}
The 14 April $2010 M_{\mathrm{S}}=7.1$ Yushu Earthquake (YE) had caused severe damage in the Jiegu township, the residential centre of Yushu Tibetan Autonomous Prefecture, Qinghai Province, China. In view of the fragile geological conditions after YE, risk assessment of secondary geohazards becomes an important concern for the reconstruction. A quantitative methodology was developed to assess the risk of debris flow by taking into account important intensity information. Debris flow scenarios were simulated with respect to rainfall events with 10,50 and $100 \mathrm{yr}$ returning period, respectively. The possible economic loss and fatalities caused by damage to buildings were assessed both in the settlement area and in the low hazard settlement area regarding the simulated debris flow events. Three modelled building types were adopted, i.e. hollow brick wood (HBW), hollow brick concrete (HBC) and reinforced concrete (RC) buildings. The results suggest that $\mathrm{HBC}$ structure achieves a good balance for the cost-benefit relationship compared with HBW and $\mathrm{RC}$ structures and thus could be an optimal choice for most of the new residential buildings in the Jiegu township. The low hazard boundary presents significant risk reduction efficiency in the $100 \mathrm{yr}$ returning debris flow event. In addition, the societal risk for the settlement area is unacceptable when the $100 \mathrm{yr}$ returning event occurs but reduces to ALARP (as low as reasonably practicable) level as the low hazard area is considered. Therefore, the low hazard area was highly recommended to be taken into account in the reconstruction. Yet, the societal risk might indeed approach an unacceptable level if one considers that YE has inevitably increased the occurrence frequency of debris flow. The quantitative results should be treated as a perspective for the reconstruction rather than precise numbers of future losses, owing to the complexity of the problem and the deficiency of data.
\end{abstract}

\section{Introduction}

The 14 April $2010 M_{\mathrm{S}}=7.1$ Yushu Earthquake (YE) not only caused nearly 3000 fatalities (Lin et al., 2011) and enormous economic loss, but also made the seismic area more prone to geological hazards. Debris flow in seismic areas is often characterized by enormous energy and by a complex behaviour consisting of high velocity and long run-out (up to tens of kilometres). They posed high risk to human lives. Since 12 May 2008, large numbers of debris flow events have occurred in the Wenchuan seismic area and have caused thousands of deaths (Xie et al., 2009; Tang and Tie, 2009; Cui et al., 2010; Xu, 2010; Yu et al., 2010). The debris flow event that took place on 7 August 2010 in Zhouqu led to more than one thousand people losing their lives (Yu et al., 2010). Studies on the Chi-Chi seismic area have shown that the threshold of accumulated rainfall for triggering debris flow would drop significantly after a large earthquake (Chen, 2008; Liu et al., 2008). The necessity of risk assessment of potential debris flow in seismic areas after a large earthquake is therefore suggested.

However, it is still challenging to conduct quantitative risk assessment of debris flow events by considering their extremely high energy and mobility. It had been recognized that determining parameters defining intensity (e.g. velocity, volume and depth of deposits) and predicting run-out distance are two most crucial aspects in geohazard risk assessment (Lan et al., 2008; Revellino et al., 2008; Liu et al., 2011). Risk to life caused by debris flow events and rockfalls in Bíldudalur, NW-Iceland, was calculated through the product of probability of event, its consequences and elements at risk (Bell and Glade, 2004). The direct and indirect economic risk map of landslides in the Bajo Deba area, northern 


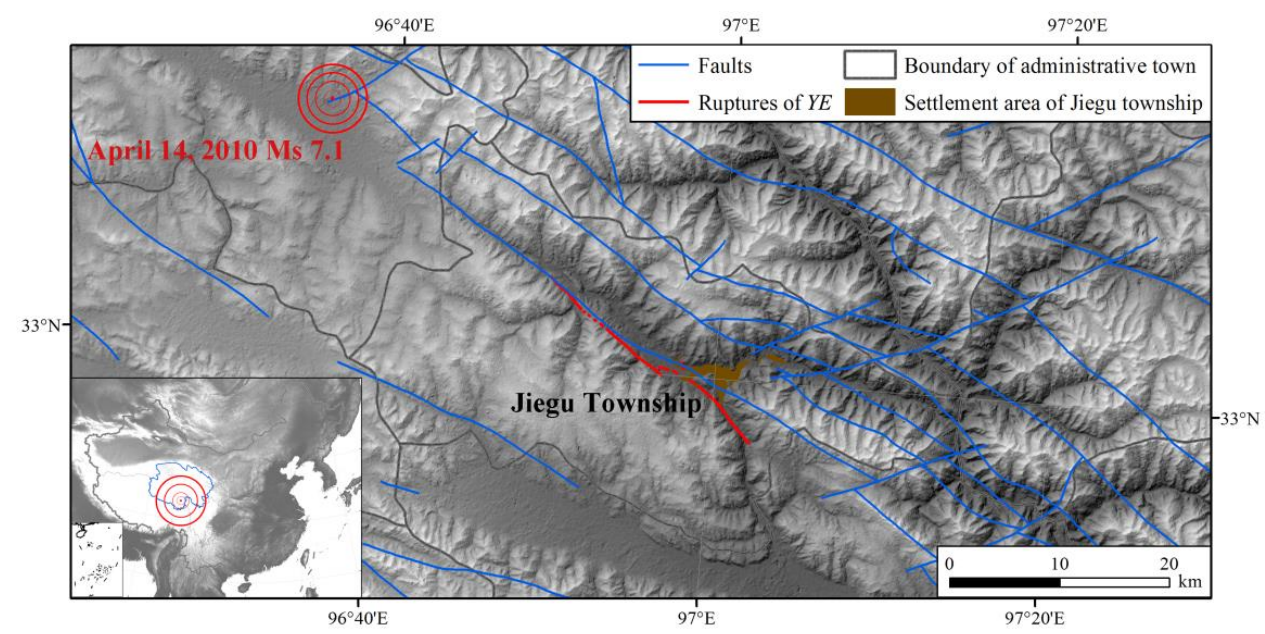

Fig. 1. Location of Jiegu township. The red concentric circles indicate the epicentre of YE. It is shown that Jiegu township is located on the Ganzi-Yushu fault zone and adjacent to the YE epicentre. The ruptures of YE mapped in field survey are presented using red lines.

Spain, was obtained based on considerations of hazard, vulnerability and valuation of exposed elements (Remondo et al., 2008), while total annual monetary risk was estimated for two debris flow gullies in the Songhe community, Taiwan, to evaluate the performance of risk reduction programs (Chen et al., 2010). Quan Luna et al. (2011) used numerical debris flow modelling to generate physical vulnerability curves for the risk assessment of debris flow events in the central part of the Valtellina Valley in northern Italy.

As the economic and inhabitant centre of the Yushu Tibetan Autonomous Prefecture, the Jiegu township was severely damaged by YE. For the purpose of reconstruction, detailed information regarding the probability of damage state for a building impacted by debris flow as well as the societal risk has to be predicted. The main objective of this study is to quantitatively assess the risk of potential debris flow events in the Jiegu township by incorporating their important intensity information so as to assist decision-making in the reconstruction. Debris flow scenarios were simulated to identify maximum run-out distances, volumes, velocities, deposit distribution and their impact pressures. The quantitative relationship between the impact of debris flow and the damage status of facilities was established by a rational model. The possible economic loss and fatalities caused by damage to buildings in simulated potential debris flow events were then estimated with respect to different scenarios of rainfall events. The risk reduction efficiencies of employing high resistance building structures and avoiding high hazard areas in the reconstruction were analysed. The associated societal risk of debris flow was also addressed.

\section{Study area}

The Jiegu township is located on the Ganzi-Yushu Fault zone, which is one of the most active fault zones in the east margin of the Tibetan Plateau (Fig. 1). The Ganzi-Yushu Fault zone strikes along NWW-SEE continuously, owing to the collision of India with the Eurasia (Gan et al., 2007), and is capable of triggering large earthquakes. Five historical earthquakes of $M>7$ have occurred along the Ganzi-Yushu fault zone over approximately the past $700 \mathrm{yr}$ (Lin et al., 2011). The Jiegu township locates about $45 \mathrm{~km}$ southeast away from the epicentre of YE (Fig. 1) and therefore suffered severe fatalities during YE.

The Yushu seismic area is characterized by typical plateau topography with an average altitude of over $4000 \mathrm{~m}$ a.s.l. It is dominated by inter-bedding Triassic sandstone and slate that are highly prone to geological failure. Incompact Quaternary fluvial, alluvial and colluvial deposits are abundant in the major valleys and their branches. The Jiegu township is located along the narrow Zhaqu River valley (Fig. 2), which is about 300-1500 m wide and about 400-1000 m lower than the surrounding high lands. The river terrace adjoining piedmont alluvial fans is heavily populated and is therefore highly vulnerable to debris flow (Fig. 3). Some parts of the township are actually located on alluvial fans formed by debris flow.

The Yushu seismic area is located in the arid and semi-arid region. Its temperature averages $3.7^{\circ} \mathrm{C}$ and differs distinctly between day and night. The mean annual precipitation is about $468 \mathrm{~mm}$, where the rainy season from May to October accounts for about $92 \%$ of total precipitation (Niu, 2011). The recorded maximum annual precipitation and maximum daily precipitation is $638.8 \mathrm{~mm}$ and $38.8 \mathrm{~mm}$, respectively. During the rainy season, rainfall events are characterized by short duration, high intensity and are highly spatial and temporal concentrated. 


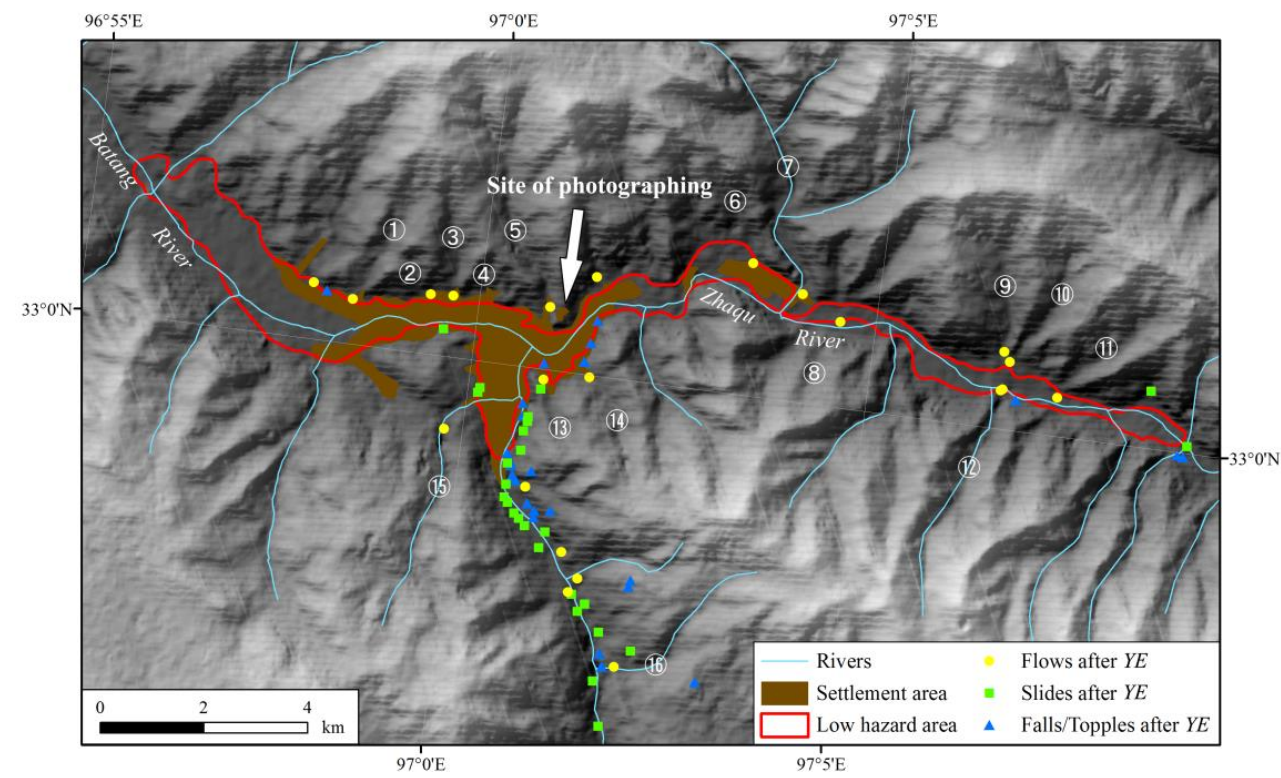

Fig. 2. Aerial view of the topographic setting of Jiegu township. The arrow indicates the site where the two photos in Fig. 3 were taken. The geological hazards after YE around Jiegu township are also shown. The hazard classification method proposed by Cruden and Varnes (1996) is adopted to classify these hazards. Circled numbers indicate the locations of the 16 gullies in which debris flow events have occurred at least once. Gully 1-5 are five gullies where the severe debris flow event on 29 July 2003 occurred. Details of these gullies and historical events are listed in Table 1. The explanation of low hazard area is given in the end of Sect. 2.

From 1957 to 2005, a total 11 notable historical debris flow events occurred in 16 gullies around the Jiegu township (Ren and Zhu, 2007; also see Fig. 2 and Table 1). On 29 July 2003, localized intense rainfall produced more than $30 \mathrm{~mm}$ precipitation within the period from 19:42 to 20:23 Beijing Time. It triggered severe debris flow events synchronously occurring in five gullies (gullies 1-5 in Fig. 2 and Table 1) in the northern mountainous area of the Jiegu township (Ren and Zhu, 2007). One person died and 11 were injured in this event. The direct economic loss exceeded RMB 25 million (USD 4 million), which is almost $80 \%$ of the annual GDP of Jiegu Town in 2002 (Xiao et al., 2005).

A primary field survey after YE detected a total $282 \mathrm{sec}-$ ondary geological hazard events (Yin et al., 2010; Fig. 2). A newer survey aided by remote sensing images showed that more than 2000 landslides were induced by YE in the Yushu seismic area (Xu et al., 2011). These secondary geological failures created a large amount of loosened material. Debris flow events were therefore easily triggered by lower rainfall intensity due to YE. It is consequently expected that debris flow would occur more frequently in the Jiegu township after YE.

A "low hazard area" for the Jiegu township (Fig. 2) was obtained by excluding the high hazard zone that was identified according to major geological hazard events (Fig. 2) and simulating scenarios of potential debris flow events (see Sect. 3.3). The settlement area of Jiegu township shown in Fig. 2 was delineated based on the interpretation of high resolution aerial images before the earthquake. It shows the real residential area before the earthquake in which high probability of geological hazard existed. The high hazard zone in the settlement area was due to the overdevelopment of urban settlement toward the mountainous regions.

\section{Methods}

\subsection{Risk, loss and vulnerability}

Risk assessment tries to answer "how safe is the element at risk". In a quantitative manner, the answer is defined by the product of probability of hazard and the undesirable consequence of loss according to most risk assessment models (Fell et al., 2005):

$R=H \times V \times E$,

in which $H$ (stands for hazard) indicates the probability of the occurrence of a hazard event, $V$ represents vulnerability and $E$ is the value of element at risk, while the product of $V$ and $E$ composes the potential losses.

Vulnerability is a crucial parameter in risk assessment. It has divergent definitions by different authors. Nevertheless, a widely accepted conception of vulnerability is the degree of loss to a given element or a set of elements within the area affected by a hazard (ISSMGE, 2004). Vulnerability depends on both the intensity of a specific hazard event and the intrinsic characteristics of the threatened element. It is expressed on a scale of 0 to 1 , where 1 means total loss of the value of an element or the life of a person. 
Table 1. Gullies surrounding Jiegu township in which debris flow events have occurred at least once and their corresponding historical events.

\begin{tabular}{rlrrrrr}
\hline ID Name & $\begin{array}{r}\text { Watershed } \\
\text { area } \\
\left(\mathrm{km}^{2}\right)\end{array}$ & $\begin{array}{r}\text { Mean slope } \\
\text { angle } \\
(\%)\end{array}$ & $\begin{array}{r}\text { Relative } \\
\text { elevation } \\
(\mathrm{m})\end{array}$ & $\begin{array}{r}\text { Year of } \\
\text { occurrence }\end{array}$ & $\begin{array}{r}\text { Maximum debris } \\
\text { discharge } \\
\left(10^{4} \mathrm{~m}^{3}\right)\end{array}$ \\
\hline 1 & De Nian Long Ba & 3.5 & 10 & 1097 & 2003 & 2.43 \\
2 & Za Sheng Long Ba & 0.5 & 15 & 880 & 2003 & 0.32 \\
3 & Ri Wo Long Ba & 2.3 & 22 & 880 & 2003 & 1.55 \\
4 & Zha Long Gou & 1.5 & 30 & 500 & 2003 & 1.01 \\
5 & Jie Gu Long Ba & 9.5 & 18 & 800 & 2003 & 6.28 \\
6 & Ri Yong Long Dong & 0.9 & 19 & 280 & 2002 & 0.58 \\
7 & Re Weng Long & 41.0 & 10 & 1100 & 2003 & 18.21 \\
8 & Zhi Rong Nan Gou & 3.1 & 13 & 350 & 2000 & 1.95 \\
9 & Shang Jian Guo Long & 4.2 & 15 & 280 & 2002 & 1.16 \\
10 & Xia Jian Guo Long & 3.5 & 20 & 320 & 1998 & 2.28 \\
11 & Dai Luo Long & 4.1 & 20 & 920 & 1998 & 2.68 \\
12 & Xian Zi Long & 5.0 & 26 & 1300 & N.A. & 3.53 \\
13 & De Wo Long Ba & 1.7 & 27 & 400 & N.A. & 1.15 \\
14 & Da Di Gou & 1.9 & 29 & 615 & 2002 & 1.26 \\
15 & Meng Zong Gou & 12.1 & 14 & 400 & 1987 & 8.38 \\
16 & Ni Long Ku & 10.2 & 26 & 800 & 1989 & 6.57 \\
\hline
\end{tabular}

${ }^{1}$ Data provided by local government of Qinghai Province and partly estimated by the authors using high resolution satellite images (QuickBird) and aerial photos. 2 "N.A." means unknown.

The total economic loss should be a summation of the loss of all elements at risk, including buildings, roads, bridges, pipelines, communication systems, and other valuable lands such as farmland and forestland, etc. Consideration of all elements at risk is only practicable for research cases focusing on a small area, e.g. with a toe length less than $1 \mathrm{~km}$ (Sterlacchini et al., 2007; Chen et al., 2010). It is not practicable for the Jiegu township which extends $20 \mathrm{~km}$ along the Zhaqu River. Additionally, the varieties and distribution of threatened elements in the crowded Jiegu city area are much more complex than the rural area (Sterlacchini et al., 2007; Chen et al., 2010). The devastation caused by YE also made elements at risk indeterminable. Therefore, only losses caused by damage to buildings were assessed in this study since buildings are the most important element during the reconstruction. It was also suggested that economic loss caused by damage to buildings would account for more than $70 \%$ of the total economic loss in the city area (Tie, 2009).

The potential loss of an individual's life varies with the location of the person. The risk of hazards to the lives of individuals residing indoors differs from that to the lives of individuals residing outdoors. No data are available for the proportion of residents staying in buildings to those staying out at a certain time and in a certain area. It is therefore not possible to assess fatalities of persons residing inside vs. outside during the simulated debris flow events. As a result, we assume that all residents are residing in buildings during the debris flow events, and therefore all fatalities are caused by damage to buildings.

\subsection{Damage state of buildings}

The total economic loss can be estimated by adding up the monetary losses of each element. However, fatalities cannot be obtained by adding up the probabilities of loss of life for individuals. A reasonable way is to assign a certain death rate to each damage state of buildings, as proposed by FEMA (2010) in the HAZUS Earthquake Technical Manual. HAZUS defines five damage states for buildings: none, slight, moderate, extensive and complete. A building repair cost ratio is also assigned to each damage state in HAZUS.

The probability of damage state of a building is directly linked to the debris flow impact intensity (i.e. hydrostatic and dynamic force). The fatality rate is then associated with the predicted damage rate of buildings. The quantitative model proposed by Haugen and Kaynia (2008) is adopted to evaluate the damage state of buildings in potential debris flow events. Following the approach of the HAZUS program, this model estimates the probability of a building to reach a certain damage state according to its maximum displacement caused by impact of debris flow. For a certain damage state, $\mathrm{ds}$, and a given maximum displacement, $u_{\max }$, the probability is defined by

$P\left(\mathrm{ds} \mid u_{\max }\right)=\Phi\left[\frac{1}{\beta_{\mathrm{ds}}} \ln \left(\frac{u_{\mathrm{max}}}{S_{\mathrm{d}, \mathrm{ds}}}\right)\right]$,

where $\Phi$ is the standard normal cumulative distribution function, $S_{\mathrm{d}, \mathrm{ds}}$ is a predefined median displacement value that corresponds to the displacement threshold of the damage state, and $\beta_{\mathrm{ds}}$ is a predefined standard deviation of the natural 


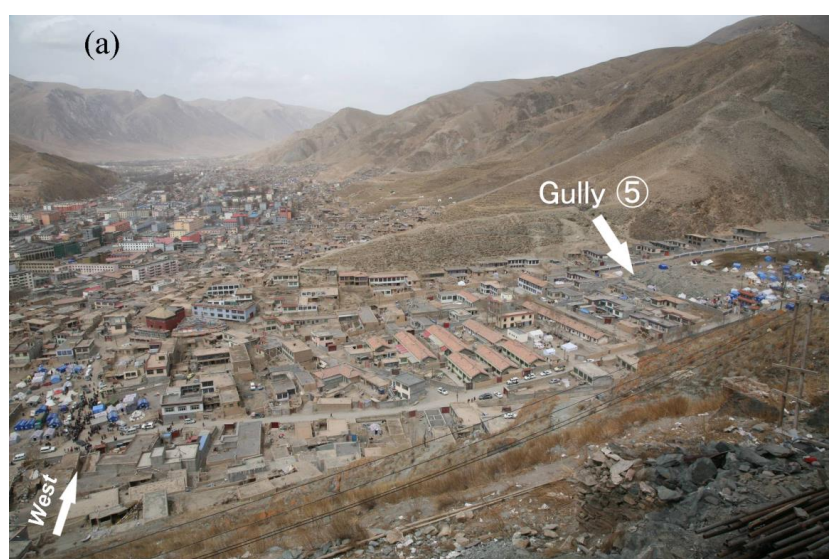

(b)

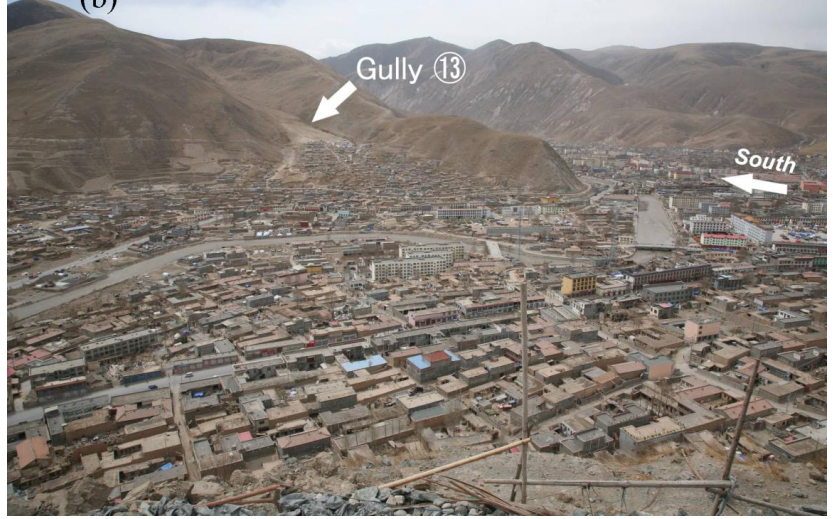

Fig. 3. Settlement area in Jiegu township. Photos were taken after YE at the site indicated in Fig. 2. (a) Looking west; (b) Looking south. It is shown that the outlets of gully 5 and gully 13 are heavily populated. Note:buildings in the east part of Jiegu township did not suffer from severe damage in YE (photos courtesy of Dr. Yueping Yin).

logarithm of maximum displacement for the damage state. The parameter $S_{\mathrm{d}, \mathrm{ds}}$ and $\beta_{\mathrm{ds}}$ are predefined with regard to the damage state and the type of building. The maximum displacement is the combination of maximum dynamic displacement $\left(\mu_{\mathrm{dy}, \max }\right)$ and static displacement $\left(\mu_{\mathrm{st}}\right)$ :

$u_{\max }=u_{\mathrm{st}}+u_{\mathrm{dy}, \max }$.

The static displacement is caused by the hydrostatic force and can be calculated:

$u_{\mathrm{st}}=\frac{P_{\mathrm{st}}}{k}=\frac{p_{\mathrm{st}} A}{k}=\frac{p_{\mathrm{st}} h b}{k}$,

where $P_{\mathrm{st}}$ and $p_{\mathrm{st}}$ are the hydrostatic force and average hydrostatic pressure respectively, $k$ is the stiffness of the building, $A$ is the area of building hit by debris flow, $h$ is the height of flow, and $b$ is the width of the building.
The maximum dynamic displacement is caused by impact force of debris flow and can be estimated:

$u_{\mathrm{dy}, \max }=R_{\max } \frac{P_{\mathrm{dy}}}{k}=R_{\max } \frac{p_{\mathrm{dy}} A}{k}=R_{\max } \frac{p_{\mathrm{dy}} h b}{k}$,

where $P_{\mathrm{dy}}$ and $p_{\mathrm{dy}}$ is the dynamic impact force and average dynamic impact pressure, respectively, and $R_{\max }$ is the ratio of the dynamic displacement to the static displacement caused by the same force amplitude.

The stiffness of a building $(k)$ can be calculated (Haugen and Kaynia, 2008):

$k=\frac{4 \pi^{2} m_{\mathrm{str}}}{T_{\mathrm{n}}^{2}}$,

where $m_{\text {str }}$ is the mass and $T_{\mathrm{n}}$ is the natural period of a building.

\subsection{Simulation of debris flow scenarios}

To evaluate the hydrostatic and dynamic force of a debris flow on buildings, the FLO-2D model (O'Brien et al., 1993) was used to simulate potential debris flow scenarios. Due to the degraded geological environment after YE, widespread debris flow events were supposed to take place in our simulation, which means that debris flow events occur synchronously in all the major gullies around the Jiegu township.

Primary input parameters for the simulation are the topography, hydrograph and rheological parameters. The high resolution digital elevation model ( $5 \mathrm{~m}$ resolution) was acquired right after the earthquake by high resolution aerial photo pairs. However it does not cover the whole study area since it focuses on the urban area. The input topography was therefore modelled by $90 \mathrm{~m}$ resolution STRM (Shuttle Radar Topography Mission) DEM (digital evaluation models) to increase the computing efficiency. The input hydrograph was designed based on the frequency-magnitude analysis of historical debris flow records (Table 1) and the rainfall intensity for different returning periods. Rainfall analysis was performed by Gumbel analysis (e.g. Koutsoyiannis, 2004) using over $50 \mathrm{yr}$ daily rainfall data available in 15 weather stations. Fig. 4 shows the rainfall intensity versus duration for different returning periods. A triangular hydrograph was established for the input flow with different rainfall scenarios that correspond to three different rainfall events with 10,50 and $100 \mathrm{yr}$ returning periods. The volume concentration of debris flow events and the time duration of events are determined referring to the widespread debris flow event on 29 July 2003 (Xiao et al., 2005). The concentrating time of $2 \mathrm{~h}$ was used. Peak discharges are estimated for the 10,50 and $100 \mathrm{yr}$ returning periods using a linear regression formula, which resulted in 93,120 and $132 \mathrm{~m}^{3} \mathrm{~s}^{-1}$, respectively.

The yield stress and viscosity are two important rheological parameters for modelling the debris flow run-out. Rheological parameters were estimated from empirical data and 


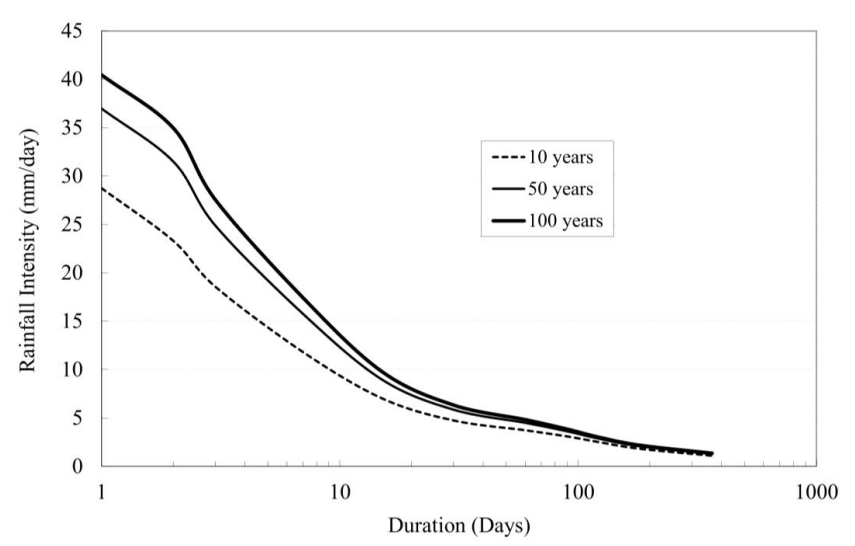

Fig. 4. The rainfall intensity versus duration for different returning periods (10-, 50- and 100-yr).

calibration using historical event data. Empirical coefficients were reported in the FLO-2D manual (FLO-2D Users Manual, 2003). Field survey has suggested that the debris materials are characterized by low viscosity. Therefore we used viscosity coefficient of 0.13 , viscosity exponent of 12 , yield stress coefficient of 2.7 and yield stress exponent of 10.4 as initial input parameters. Finer calibration was performed with a trial-and-error procedure by comparing with field survey data. The modelling results match well with historical events in terms of travelling path and deposition. However, the modelling uncertainty is still a concern when taking into account the different returning scenarios. Adequate data are necessary to improve the frequency-magnitude analysis of debris flow hazard and rainfall analysis, as well as to help validate modelling.

The modelling predicts the flow depth, hydrostatic pressure and dynamic pressure of the simulated widespread debris flows. The results related to rainfall with returning period of $100 \mathrm{yr}$ are presented in Fig. 5. Such results help identify the high hazard zone in the study area and further define the low hazard area (Fig. 2). The simulation of potential debris flow events shows that flow velocity maintains a destructive level in places $200-500 \mathrm{~m}$ away from the gully outlets. Accordingly, areas less than 200-500 m away from the outlets of those gullies without any reduction measures are regarded as high hazard zone. While for those gullies with reduction measures (e.g. dykes), the influencing radius (outlet as the centre) of debris flow could reduce to $50 \mathrm{~m}$. According to Fig. 2, some parts of the settlement area actually locate beyond the low hazard area. It could be suggested that the consideration of this restriction in the reconstruction of the Jiegu township is capable of avoiding potential severe geological hazards after YE.
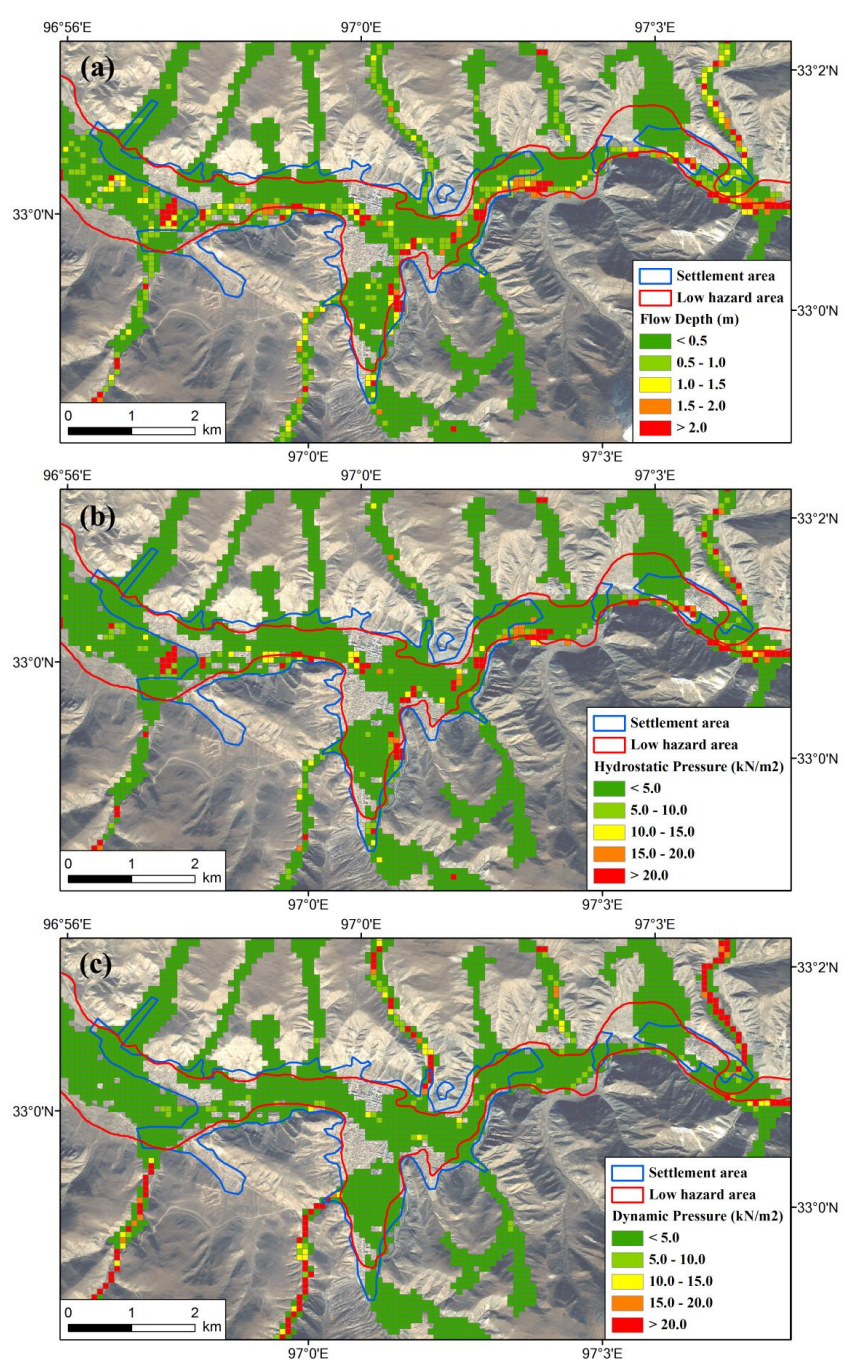

Fig. 5. The simulated debris flow event with a returning period of 100 yr: (a) flow depth; (b) hydrostatic pressure; (c) dynamic pressure.

\section{Results}

\subsection{Assumptions of modelled buildings}

Once the hydrostatic and dynamic pressures of debris flow events are available, the parameters of a certain building, like structural type, mass and dimensions as well as its location, are needed to evaluate its maximum displacement caused by impact of debris flow. During YE, more than half of the buildings in the Jiegu township collapsed (Guo et al., 2010). A large number of new buildings are therefore about to be constructed. It is not practical to get the detailed parameters of new buildings and of buildings that survived in YE. As a result, it is simply assumed that buildings with the same parameters (i.e. structural type, mass and 3-D dimension) are uniformly distributed in the study area. According to the current situation in the Jiegu township, all buildings 
Table 2. Parameters of the modelled building types.

\begin{tabular}{lrrrrrr}
\hline Type & Stories & $\begin{array}{r}\text { Height } \\
(\mathrm{m})\end{array}$ & $\begin{array}{r}\text { Ground area } \\
\left(\mathrm{m}^{2}\right)\end{array}$ & $\begin{array}{r}\text { Mass } \\
\left(10^{3} \mathrm{~kg}\right)\end{array}$ & $\begin{array}{r}T_{\mathrm{n}}^{4} \\
(\mathrm{~s})\end{array}$ & $\begin{array}{r}k^{5} \\
\left(\mathrm{MN} \mathrm{m}^{-1}\right)\end{array}$ \\
\hline $\mathrm{HBW}^{1}$ & 2 & 6 & $20 \times 9$ & 101 & 0.19 & 110 \\
$\mathrm{HBC}^{2}$ & 2 & 6 & $20 \times 9$ & 146 & 0.19 & 160 \\
$\mathrm{RC}^{3}$ & 2 & 6 & $20 \times 9$ & 299 & 0.23 & 223 \\
\hline
\end{tabular}

are supposed to have a height of $6 \mathrm{~m}$. High resolution aerial images show that the average ground area of buildings in the Jiegu township is about $180 \mathrm{~m}^{2}$. Therefore, the length, width and height of modelled buildings are set to $20 \mathrm{~m}, 9 \mathrm{~m}$ and $6 \mathrm{~m}$, respectively (see Table 2). This modelled building provides a unit of risk assessment of debris flow for the reconstruction of the Jiegu township.

The low resistance of buildings in the Yushu seismic area to natural hazards significantly aggravated the economic loss and fatalities in YE. Field survey shows that about $45 \%$ of the buildings in the Yushu seismic area are adobe wood structure or rubble structure; about $30 \%$ are hollow brick wood (HBW) structure; about $15 \%$ are hollow brick concrete (HBC) structure; while reinforced concrete (RC) structure accounts for only about $10 \%$ (Liu et al., 2010). In YE, almost all of the adobe wood structures collapsed; about $85 \%$ of HBW structures and about $60 \%$ of HBC structures collapsed or were severely damaged; while of RC structures only about $30 \%$ were damaged (Liu et al., 2010). HBW, HBC and RC structures dominate the building structural type in the Jiegu township. Potential losses were therefore assessed based on these three structural types. The masses of a single $\mathrm{HBW}, \mathrm{HBC}$ and $\mathrm{RC}$ building were estimated according to their assumed 3-D dimensions and the densities of construction materials (GB 50009-2001). The natural periods of each building type were estimated using the equation proposed by ASCE (2006), while the stiffness of each type were calculated using Eq. (6). The parameters of the three modelled building types are shown in Table 2 .

\subsection{Loss assessment}

The dynamic pressure and hydrostatic pressure of potential debris flow events are available for each $90 \mathrm{~m} \times 90 \mathrm{~m}$ cell. The potential maximum displacement of a building caused by debris flow in each cell was calculated using Eqs. (3)-(5) for each building type. The ratio of the dynamic displacement to the static displacement caused by the same force amplitude $\left(R_{\max }\right)$ in Eq. (5) is assumed to be 2 since the debris flow pulses will last longer than $T_{\mathrm{n}} / 2$ (Haugen and Kaynia, 2008). The parameters $S_{\mathrm{d}, \mathrm{ds}}$ and $\beta_{\mathrm{ds}}$ of each building type at a given damage state are required to calculate the probability of a certain building type to reach a certain damage state in a cell. These parameters were obtained from the HAZUS Earthquake Technical Manual (FEMA, 2010). As HBW, HBC and RC are not included in the 36 building types classified by HAZUS, the equivalent URML (low-rise unreinforced masonry bearing walls structure), RM2L (lowrise reinforced masonry bearing walls with precast concrete diaphragms structure) and C1L (low-rise concrete moment frame structure) were selected to represent HBW, HBC and $\mathrm{RC}$, respectively. The values of $S_{\mathrm{d}, \mathrm{ds}}$ and $\beta_{\mathrm{ds}}$ for the three modelled building types are shown in Table 3 .

Haugen and Kaynia (2008) gave the probabilities between $34 \%$ and $66 \%$ for reaching the damage levels that actually occurred. Considering the lower resistance of HBW, HBC and RC buildings in the Jiegu township, the lowest standard was adopted. It is supposed that the damage state will actually be reached if the modelling probability exceeds $30 \%$. For a building hit by debris flow with a given maximum displacement, each of the damage states listed in Table 3 has an estimated probability of occurrence. The damage state with an estimated probability of occurrence that exceeds $30 \%$ is taken as the prospective damage state.

The repair cost ratios for each damage state as well as the indoor mortalities (mortality among individuals residing indoors) for each building type in a certain damage state are given in the HAZUS Earthquake Technical Manual (FEMA, 2010). The indoor mortality for a completely damaged building with collapse is much higher than that for a completely damaged building without collapse. The collapse rates in the complete damage state of each modelled building type are adjusted according to the actual collapse rates of buildings in the Jiegu township for YE (Guo et al., 2010; Liu et al., 2010). The collapse rates $80 \%, 50 \%$ and $15 \%$ in complete damage state are assigned to HBW, HBC and RC buildings, respectively. The repair cost ratios and indoor mortalities used in this study are listed in Table 4.

The simulated dynamic pressure and hydrostatic force of debris flow in each cell determine the damage state and therefore the repair cost ratio and indoor mortality of a given building type. A uniform repair cost ratio and a uniform indoor mortality are assigned to each $90 \mathrm{~m} \times 90 \mathrm{~m}$ cell with regard to the concerned building types and simulated debris flow scenarios. The total value of buildings and total number of residents in each cell are then required to assess the 
Table 3. The median displacement threshold to reach a certain damage state $\left(S_{\mathrm{d}, \mathrm{ds}}\right)$ for modelled building types and their corresponding log-normal standard deviation $\left(\beta_{\mathrm{ds}}\right)$.

\begin{tabular}{lrrrrrrrrr}
\hline \multirow{2}{*}{ Damage State } & \multicolumn{2}{c}{$\mathrm{HBW}$} & & \multicolumn{2}{c}{$\mathrm{HBC}$} & & \multicolumn{2}{c}{$\mathrm{RC}$} \\
\cline { 2 - 3 } \cline { 8 - 9 } \cline { 8 - 9 } & $S_{\mathrm{d}, \mathrm{ds}}(\mathrm{cm})$ & $\beta_{\mathrm{ds}}$ & & $S_{\mathrm{d}, \mathrm{ds}}(\mathrm{cm})$ & $\beta_{\mathrm{ds}}$ & & $S_{\mathrm{d}, \mathrm{ds}}(\mathrm{cm})$ & $\beta_{\mathrm{ds}}$ \\
\hline Complete & 9.60 & 1.18 & & 16.00 & 0.92 & & 18.29 & 0.97 \\
Extensive & 4.11 & 1.20 & & 5.87 & 1.15 & & 7.32 & 0.90 \\
Moderate & 1.65 & 1.19 & & 2.34 & 1.10 & & 2.92 & 0.94 \\
Slight & 0.81 & 1.15 & & 1.47 & 1.14 & & 1.83 & 0.98 \\
\hline
\end{tabular}

Table 4. The repair cost ratios and indoor mortalities for different damage states of buildings.

\begin{tabular}{lrrrr}
\hline \multirow{2}{*}{ Damage state } & Repair cost ratio & \multicolumn{3}{c}{ Indoor mortality (\%) } \\
\cline { 3 - 5 } & & HBW & HBC & RC \\
\hline Complete & 1.00 & 8.00 & 5.01 & 1.51 \\
Extensive & 0.45 & 0.002 & 0.001 & 0.001 \\
Moderate & 0.10 & 0.001 & 0 & 0 \\
Slight & 0.02 & 0 & 0 & 0 \\
\hline
\end{tabular}

loss of money and lives caused by damage to buildings. The high resolution aerial images show there are on average 14.5 buildings within one cell, which figures out a construction area of $5220 \mathrm{~m}^{2}$. The construction cost per square metres for HBW, HBC and RC buildings in the Jiegu Town is about USD 190, 235 and 315, respectively, according to local survey (Liu et al., 2010). The total value of buildings in one cell is then calculated to be USD $0.99,1.23$ and 1.64 million for HBW, HBC and RC type, respectively. The population density is 10483 persons per $\mathrm{km}^{2}$. There are about 85 persons residing in each $90 \mathrm{~m} \times 90 \mathrm{~m}$ cell by assuming even distribution.

To evaluate the risk reducing effect, the loss of economy and the loss of lives caused by damage of buildings were assessed both in the settlement area and in the low hazard settlement area. The low hazard settlement area is an intersection of the settlement area and the low hazard area. The quantitative results are presented in Table 5.

\section{Discussion and conclusions}

\subsection{Perspective for the reconstruction}

The structural type of new buildings and the resettlement location are two essential issues that should be preferentially addressed in the reconstruction of the Jiegu township. The proportion of low hazard settlement area to the settlement area is about 0.72 . Supposing the total economic loss caused by damage to buildings in the settlement area is 1 , the relative economic losses for the low hazard settlement area are 0.66 , 0.72 and 0.50 for simulated events with returning period of
$10 \mathrm{yr}, 50 \mathrm{yr}$ and $100 \mathrm{yr}$, respectively. The risk reducing efficiency of the low hazard area is not significant for debris flow scenarios with $10 \mathrm{yr}$ and $50 \mathrm{yr}$ returning periods. The decreasing rate of economic loss $(0.50)$ is much more significant for an event with returning period of $100 \mathrm{yr}$. This suggests that the extension of the resettlement area of the Jiegu township during reconstruction should be restricted in the low hazard area so as to substantially reduce the potential losses caused by possible high intensity debris flow events. Regarding a debris flow event with $100 \mathrm{yr}$ returning period, the possible fatalities associated with HBW structure drops from 20.43 to 0.79 , as the low hazard area is considered (Table 5c). This implies the adoption of the low hazard area has significant risk reducing efficiency in the aspect of both economic loss and human fatality. It should be noted that the returning period of high intensity debris flow events would significantly reduce due to the influence of earthquake. Therefore the restriction of the extension of the Jiegu township should be seriously respected during the reconstruction.

The risk reducing efficiency of employing $\mathrm{HBC}$ and $\mathrm{RC}$ buildings were also evaluated. Assuming the economic loss when employing the HBW structure is 1, the decrease ratios of economic loss when employing the HBC structure are $0.76,0.70$ and 0.62 for events with returning periods of $10 \mathrm{yr}$, $50 \mathrm{yr}$ and $100 \mathrm{yr}$, respectively, while the decrease ratios of economic loss when employing the RC structure are 0.97, 0.87 and 0.86 , respectively. The increase ratios of construction costs when employing HBC and RC buildings compared with $\mathrm{HBW}$ buildings are 0.25 and 0.67 , respectively. For all simulated events, the cost-benefit ratio of adopting the $\mathrm{RC}$ structure is higher than that of using the HBC structure.

It is worth noting that the HBW structure may easily reach a more severe damage state compared with the HBC structure when impacted by the same forces because of the HBW structure's significant lower stiffness and lower threshold of displacement to reach a certain damage state (Tables 2 and 3 ). Fatalities caused by a simulated debris flow event with returning period of $100 \mathrm{yr}$ in the settlement area drop to almost 0 from 20.43 when building structure type changes from HBW to HBC (Table 5c). The HBC structure is therefore suggested to be an optimum choice of residential building type during the reconstruction, considering the poor economic condition of the Jiegu township. 
Table 5. Assessed economic loss and fatalities due to damage of buildings caused by potential debris flow events simulated with rainfall events with $10 \mathrm{yr}(\mathbf{a}), 50 \mathrm{yr}$ (b) and $100 \mathrm{yr}$ (c) returning period.

(a) $10 \mathrm{yr}$ returning period

\begin{tabular}{lrrrrrr}
\hline \multirow{2}{*}{ Building type } & \multicolumn{2}{c}{ Settlement area } & & \multicolumn{2}{c}{ Low hazard settlement area ${ }^{1}$} \\
\cline { 2 - 3 } & $\begin{array}{c}\text { Economic loss } \\
\text { (million USD) }\end{array}$ & $\begin{array}{c}\text { Fatalities } \\
\text { (persons) }\end{array}$ & & $\begin{array}{l}\text { Economic loss } \\
\text { (million USD) }\end{array}$ & $\begin{array}{r}\text { Fatalities } \\
\text { (persons) }\end{array}$ \\
\hline HBW & 0.14 & 0 & & 0.081 & 0 \\
HBC & 0.032 & 0 & & 0.021 & 0 \\
RC & 0.0044 & 0 & & 0.0033 & 0
\end{tabular}

(b) 50 yr returning period

\begin{tabular}{lrrrrr}
\hline \multirow{2}{*}{ Building type } & \multicolumn{2}{c}{ Settlement area } & & \multicolumn{2}{c}{ Low hazard settlement area } \\
\cline { 2 - 3 } \cline { 6 - 7 } & $\begin{array}{l}\text { Economic loss } \\
\text { (million USD) }\end{array}$ & $\begin{array}{l}\text { Fatalities } \\
\text { (persons) }\end{array}$ & & $\begin{array}{l}\text { Economic loss } \\
\text { (million USD) }\end{array}$ & $\begin{array}{r}\text { Fatalities } \\
\text { (persons) }\end{array}$ \\
\hline HBW & 0.86 & 0.0043 & & 0.60 & 0.0033 \\
HBC & 0.25 & 0 & & 0.17 & 0 \\
RC & 0.11 & 0 & & 0.084 & 0 \\
\hline
\end{tabular}

(c) $100 \mathrm{yr}$ returning period

\begin{tabular}{lrrrrr}
\hline \multirow{2}{*}{ Building type } & \multicolumn{2}{c}{ Settlement area } & & \multicolumn{2}{c}{ Low hazard settlement area } \\
\cline { 2 - 3 } & $\begin{array}{l}\text { Economic loss } \\
\text { (million USD) }\end{array}$ & $\begin{array}{r}\text { Fatalities } \\
\text { (persons) }\end{array}$ & & $\begin{array}{l}\text { Economic loss } \\
\text { (million USD) }\end{array}$ & $\begin{array}{r}\text { Fatalities } \\
\text { (persons) }\end{array}$ \\
\hline HBW & 9.79 & 20.43 & & 5.60 & 0.79 \\
HBC & 3.70 & 0.0026 & & 1.69 & 0 \\
RC & 1.37 & 0 & & 0.63 & 0 \\
\hline
\end{tabular}

${ }^{1}$ Settlement area with high hazard zone excluded.

\subsection{Societal risk analysis}

Societal risk aims to describe the response of the whole society to a large number of fatalities in a single event. Unlike individual risk, the societal risk is directly related to the population size exposed to the event. The society would not accept a large number of fatalities even if the risk per individual was small (Kumamoto, 2007). The societal risk can be expressed by $N-F$ curves, in which $F$ indicates the annual frequency of $N$ or more fatalities caused by the same event (Kumamoto, 2007).

Usually the societal risk criteria have to be developed with regard to the particular region, ideally by a discourse involving participants such as scientists, governors and local residents, etc. The societal risk criterion proposed by ERM-Hong Kong Ltd (1998) (Fig. 6) was adopted as a benchmark for the Jiegu township. Note that this societal risk criterion is designed for a reference toe length of the natural hillside of $0.5 \mathrm{~km}$. The suggested upper bound of risk threshold with regard to the Jiegu township (upper dashed line in Fig. 6) moves up 40 times compared with the original line of ERMHong Kong Ltd (1998) since the length of the settlement area of the Jiegu township is about $20 \mathrm{~km}$, which is 40 times of $0.5 \mathrm{~km}$ as suggested by ERM-Hong Kong Ltd (1998) and Ho et al. (2000).
The lower bound of risk threshold was determined by historical data (lower dashed line in Fig. 6). Nearly 50 years of historical records show that 11 notable debris flow events occurred around the Jiegu township from 1957 to 2005, during which time only the event that occurred on 29 July 2003 caused casualties to people (Ren and Zhu, 2007): one person died and 11 persons were injured. In fact, the death of a single person is highly accidental. Therefore the 1 fatality with annual probability of $1 / 50$ suggests the lower bound of the risk threshold. The historical record thus agrees with the modelling result that debris flow events with $10 \mathrm{yr}$ and $50 \mathrm{yr}$ returning period may not cause fatalities. The $\mathrm{N}-\mathrm{F}$ points corresponding to HBW structures in both the original settlement area and the low hazard settlement area are considered (Fig. 6). The results of quantitative risk assessment show that the simulated event with returning period of $100 \mathrm{yr}$ may cause about 20 deaths in the settlement area if the HBW building structure is employed. This number drops to 1 when low hazard area is considered.

The influence of YE on the societal risk of debris flow is also evaluated. The effect of a large earthquake on reducing the rainfall triggering threshold is significant. It is suggested that the threshold of accumulated rainfall for triggering debris flow in the Chi-Chi seismic area would drop to about 1/4 
to $1 / 2$ of the value before an earthquake (Chen, 2008; Liu et al., 2008). Another effect is the increase of loosened material. Empirical method is usually used to estimate the increasing magnitude of loosened material after a large earthquake. Both of the two effects substantially increase the occurrence frequency of debris flow events. Assuming YE tripled the frequency of debris flow events in the Jiegu township, the $N-F$ points after YE are presented for the settlement area and the low hazard settlement area (Fig. 6).

According to the suggested $N-F$ criteria for the Jiegu township in Fig. 6, if the HBW structure is employed, the societal risk of debris flow related to the original settlement area is unacceptable, while the societal risk falls into the ALARP (as low as reasonably practicable) range when the low hazard area is adopted. It is also shown that the societal risk is approaching unacceptable when considering the potential influence of earthquake, i.e. the increase of the frequency of catastrophic debris flow events.

\subsection{Uncertainties and limitations}

Quantitative risk assessment for debris flow problems is such a complex problem that uncertainties and limitations exist in many aspects of its procedure. The data quality and their availability in our study area are major concerns. Generally, uncertainties and limitations can be examined with regard to the three items on the right side of Eq. (1), i.e. probability, vulnerability and the elements at risk.

Given the complexity of the study area, the methodology primarily focuses on the economic loss and fatalities caused by the damage to buildings. The parameters of modelled buildings are averagely treated in the spatial scope due to the lack of detailed information regarding destruction caused by the earthquake. It is also a subjective assumption that all residents are residing in buildings during the debris flow events. Uncertainties also exist in the determination of vulnerabilities. More precise input parameters and high resolution DEM may facilitate more sophisticated simulations of debris flow events and more reliable assessments of risk. The probability of a building to reach a certain damage state was assumed to obey a standard normal cumulative distribution. Empirical analyses are conducted to support the parameters estimations for modelled buildings like their natural period, stiffness, and threshold of displacement reaching a certain damage state. Uncertainties should also be taken into account when evaluating the effect of earthquake and rainfall on the frequency of debris flow events.

The practical risk threshold should be the ultimate negotiated result between the population, decision-makers, legislative representatives, stakeholders, etc. There are usually no generally valid limits of acceptable risks. The risk threshold may also change in response to changes in the socioeconomic situations. To employ an external societal risk criterion is another limitation. Although the 50 years of historical data have been taken into account to help determine the

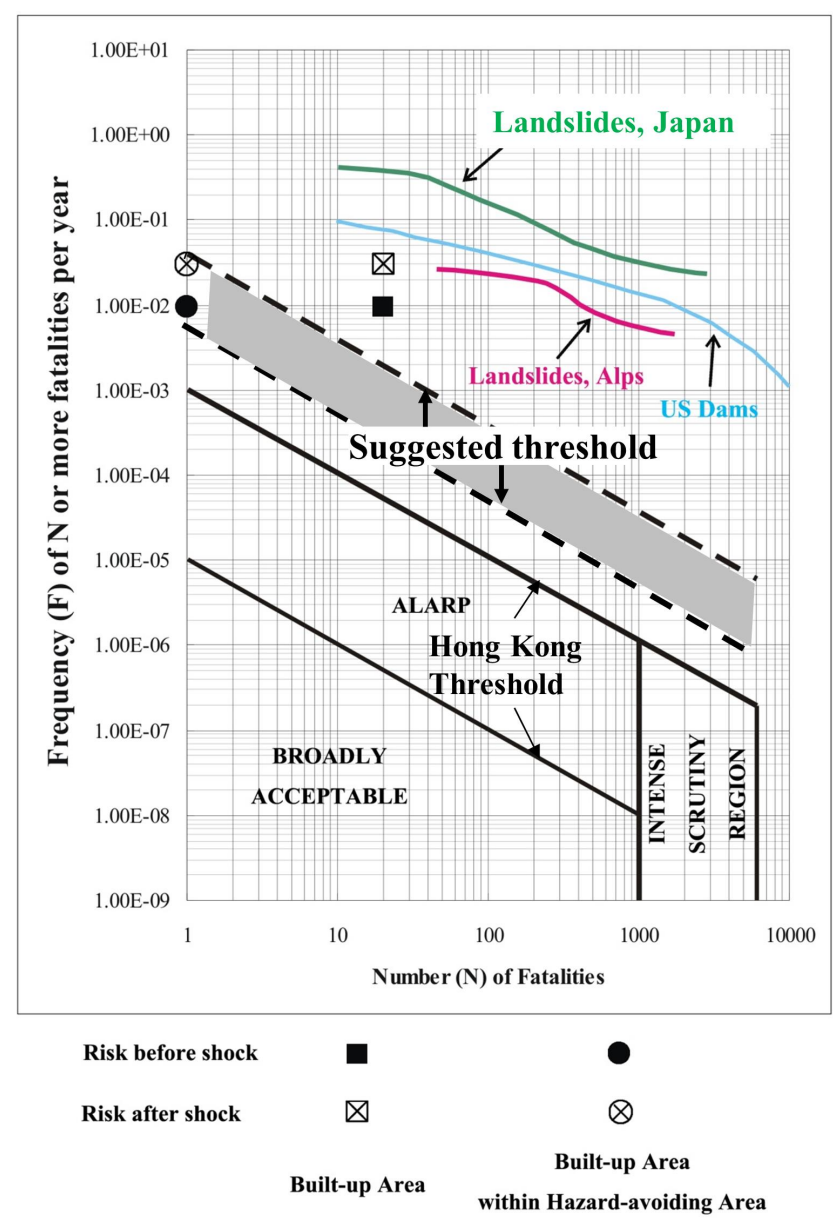

Fig. 6. The societal risk of debris flow in both the settlement area and the low hazard settlement area. The risk criterion proposed by ERM-Hong Kong Ltd (1998) is presented. Dashed lines indicate the suggested range of threshold for the debris flow risk in Jiegu township at a regional scale. YE refers to the 14 April $2010 M_{\mathrm{S}}=7.1$ Yushu Earthquake. ALARP is the abbreviation for "as low as reasonably practicable". The landslide risk at a national scale in Japan and a large regional scale in Alps (Ashby and Lenting, 2003) are also shown, suggesting the establishment of risk criteria is a scale and site related issue.

risk threshold, the current approach for the determination of acceptance is rather crude in the study area. A more practical risk threshold should be reached by balancing the various societal risks between experts, decision makers and the general society.

Nevertheless, the proposed quantitative procedure provides an insight into the risk assessment of secondary geological hazards in the seismic area.

\subsection{Concluding remarks}

The risk of debris flow events in the Jiegu township after YE (the 14 April $2010 M_{\mathrm{S}}=7.1$ Yushu Earthquake) was quantitatively assessed to provide a perspective for the 
reconstruction. The possible losses of economy and lives caused by damage to buildings were estimated by taking into account the important intensity information of debris flow. It was suggested that the linkage among the impact intensity of debris flow, the damage state of buildings and the fatality rate plays an important role in such quantitative risk assessment.

Quantitative results show that the adoption of HBC (hollow brick concrete) buildings would bring significant risk reducing effect to economic loss and fatalities. As the low hazard area is applied, the economic loss and fatalities drop significantly, and the societal risk also moves from unacceptable level to ALARP level. However, owing to the effect of YE, which significantly reduced the rainfall threshold for triggering high intensity debris flow, the societal risk tends to the unacceptable level. Concerning degraded geological environment after YE, the standard of resistance of new buildings and the planning of the resettlement boundary should be seriously addressed. Despite accompanied by uncertainties and limitations, this work presents a practical example to quantitatively assess the risk of secondary geological hazards in seismic areas in support of their reconstruction.

Acknowledgements. This research was supported by the National Science Foundation of China (41072241, 41272354), China Special Project of Basic Work of Science and Technology (2011FY1101002) and the State Grid research program. The authors are grateful to anonymous reviewers for their comments for improving the manuscript.

Edited by: T. Glade

Reviewed by: three anonymous referees

\section{References}

ASCE: Minimum Design Loads for Buildings and Other Structures, ASCE/SEI 7-05, 2006.

Ashby, G. and Lenting, V.: Thames Coast Flood Risk Assessment - Final Report, URS New Zealand Limited, Christchurch, New Zealand, 2003.

Bell, R. and Glade, T.: Quantitative risk analysis for landslides - Examples from Bíldudalur, NW-Iceland, Nat. Hazards Earth Syst. Sci., 4, 117-131, doi:10.5194/nhess-4-117-2004, 2004.

Chen, S. C., Wu, C. Y., and Huang, B. T.: The efficiency of a risk reduction program for debris-flow disasters - a case study of the Songhe community in Taiwan, Nat. Hazards Earth Syst. Sci., 10, 1591-1603, doi:10.5194/nhess-10-1591-2010, 2010.

Chen, Y. S.: An influence of earthquake on the occurrence of landslide and debris flow, PhD Thesis, National Cheng Kung University, Taipei, 2008 (in Chinese with English abstract).

Cruden, D. M. and Varnes, D. J.: Landslide types and processes, in: Landslides: Investigation and Mitigation, edited by: Turner, A. K. and Shuster, R. L., Transp Res Board, Spec Rep 247, 36-75, 1996.

Cui, P., Huang, J. Q., and Chen, X. C.: Characteristics and countermeasures of debris flow in Wenchuan area after the earthquake,
Journal of Sichuan University (Engineering Science Edition), 42, 10-19, 2010 (in Chinese with English abstract).

ERM-Hong Kong Ltd: Landslides and Boulder Falls from Natural Terrain: Interim Risk Guidelines (GEO Report No. 75), Report prepared by the Geotechnical Engineering Office, Hong Kong, 1998.

Fell, R., Ho, K. K. S., and Lacasse S.: A framework for landslide risk assessment and management, in: Landslide risk management, Proceedings of the International Conference on Landslide Risk Management, edited by: Hungr, O., Fell, R., Couture, R., and Eberhardt, E., Vancouver, Canada, 3-25, 2005.

FEMA: Multi-hazard Loss Estimation Methodology, Earthquake Model, HAZUS-MH-MR5, Technical Manual, 2010.

FLO-2D: Users manual, Version 2003.06, Nutrioso, Arizona, USA, 2003.

Gan, W. J., Zhang, P. Z., Shen, Z. -K., Niu, Z. J., Wang, M., Wan, Y. G., Zhou, D. M., and Cheng, J.: Present-day crustal motion within the Tibetan Plateau inferred from GPS measurements, J. Geophys. Res., 112, B08416, doi:10.1029/2005JB004120, 2007.

GB 50009-2001: Load code for the design of building structures, National Standard of People's Republic of China, 2001 (in Chinese).

Guo, H. D., Zhang, B., and Lei L. P.: Spatial distribution and inducement of collapsed buildings in Yushu earthquake based on remote sensing analysis, Science in China Earth Science, 53, 794-796, 2010.

Haugen, E. D. and Kaynia, A. M.: Vulnerability of structures impacted by debris flow, in: Landslides and Engineered Slopes: From the Past to the Future, edited by: Zuyu Chen, Jianmin Zhang, Zhongkui Li, Faquan Wu, and Ken Ho, Vols 1 and 2, 381-387, 2008.

Ho, K. K. S., Leroi, E., and Roberds, W. J.: Quantitative risk assessment: application, myths and future direction, in: Proceeding of GeoEng 2000 - An International Conference on Geotechnical and Geological Engineering, Melbourne, Technomic Publishing, Lancaster, PA, 269-312, 2000.

ISSMGE: Glossary of Risk Assessment Terms - Version 1, July 2004, by ISSMGE TC32 - Technical Committee on Risk Assessment and Management, 2004.

Koutsoyiannis, D.: Statistics of extremes and estimation of extreme rainfall, 1, Theoretical investigation, Hydrol. Sci. J., 49, 575590, 2004.

Kumamoto, H.: Satisfying Safety Goals by Probabilistic Risk Assessment, Springer-Verlag London Limited, 2007.

Lan, H. X., Martin, C. D., and Zhou, C. H.: Estimating the size and travel distance of Klapperhorn Mountain debris flows for risk analysis along railway, Canada, Int. J. Sediment Res., 23, 275282, 2008.

Lin, A. M., Jia, D., Rao, G., Yan, B., Wu, X. J., and Ren, Z. K.: Recurrent morphogenic earthquakes in the past millennium along the strike-llip Yushu Fault, Central Tibetan Plateau, B. Seismol. Soc. Am., 101, 2755-2764, 2011.

Liu, C. N., Huang, H. F., and Dong, J. J.: Impacts of September 21, 1999 Chi-Chi earthquake on the characteristics of gully-type debris flows in central Taiwan, Nat. Hazards, 47, 349-368, 2008.

Liu, H. J., Lan, H. X., Liu, Y., and Zhou, Y.: Characteristics of spatial distribution of debris flow and the effect of their sediment yield in main downstream of Jinsha River, China, Environ. Earth Sci., 64, 1653-1666, 2011. 
Liu, J. F., Shi, P. J., and Fan, Y. D.: Features and revelation of The April 14, 2010 Yushu Earthquake disaster in Qinghai Province, Journal of Beijing Normal University (Natural Science), 46, 630633, 2010 (in Chinese with English abstract).

Niu, Q. F.: Study on the method of geological disaster risk assessment based on GlS-A case study in "4.14" Yushu earthquake, PhD Thesis, Lanzhou University, Lanzhou, China, 2011 (in Chinese with English abstract).

O’Brien, J. S., Julien, P. Y., and Fullerton, W. T.: Two-dimensional water flood and mudflow simulation, J. Hydraul. Eng., 119, 244 261, 1993.

Quan Luna, B., Blahut, J., van Westen, C. J., Sterlacchini, S., van Asch, T. W. J., and Akbas, S. O.: The application of numerical debris flow modelling for the generation of physical vulnerability curves, Nat. Hazards Earth Syst. Sci., 11, 2047-2060, doi:10.5194/nhess-11-2047-2011, 2011.

Remondo, J., Bonachea, J., and Cendrero, A.: Quantitative landslide risk assessment and mapping on the basis of recent occurrences, Geomorphology, 94, 496-507, 2008.

Ren, Y. S. and Zhu, H. J.: The reason analysis and prevention measures of debris flow of the north mountain in Jiegu Town, Yushu County, Qinghai Province, in: Paper Collection of the 2007 Annual Symposium of Chinese Society on Economics of Geology \& Mineral Resources, edited by: Zhao, C. G. and Qi, Y. B., 618620, 2007 (in Chinese).

Revellino, P., Guadagno, F. M., and Hungr O.: Morphological methods and dynamic modeling in landslide hazard assessment of the Campania Apennine carbonate slope, Landslides, 5, 59-70, 2008.

Sterlacchini, S., Frigerio, S., Giacomelli, P., and Brambilla, M.: Landslide risk analysis: a multi-disciplinary methodological approach, Nat. Hazards Earth Syst. Sci., 7, 657-675, doi:10.5194/nhess-7-657-2007, 2007.
Tang, C. and Tie, Y. B.: Reconnaissance and analysis on the rainstorm induced debris flow in Weijiagou Valley of Beichuan City after the Wenchuan earthquake, J. Mountain Sci., 27, 652-630, 2009 (in Chinese with English abstract).

Tie, Y. B.: The methodology and framework study of urban debris flow risk assessment, $\mathrm{PhD}$ Thesis, Chengdu University of Technology, Chengdu, China, 2009 (in Chinese with English abstract).

Xiao, H. B., Cairenzhaxi, Gelebade, Pan, F. Q., and Ren, Z. Q.: The reason of the "2003.7.29" north mountain debris flow events in Jiegu township, Yushu County, Qinghai Science and Technology, 1, 37-39, 2005 (in Chinese).

Xie, H., Zhong, D. L., and Jiao, Z.: Debris flow in Wenchuan quakehit area in 2008, Journal of Mountain Science, 27, 501-509, 2009 (in Chinese with English abstract).

Xu, C., Xu, X. W, Dai, F. C., and Wang, Y. Y.: Analysis of spatial distribution and controlling parameters of landslides triggered by the April 14, 2010 Yushu earthquake, Journal of Engineering Geology, 19, 505-510, 2011 (in Chinese with English abstract).

$\mathrm{Xu}, \mathrm{Q}$.: The 13 August 2010 catastrophic debris flows in Sichuan Province: characteristics, geneticmechanism and suggestions, Journal of Engineering Geology, 18, 596-608, 2010 (in Chinese with English abstract).

Yin, Y. P., Zhang, Y. S., Ma, Y. S., Hu, D. G., and Zhang, Z. C.: Research on major characteristics of geohazards induced by the Yushu Ms 7.1 earthquake, Journal of Engineering Geology, 18, 289-296, 2010 (in Chinese with English abstract).

Yu, B., Yang, Y. H., and Su, Y. C.: Research on the giant debris flow hazards in Zhouqu County, Gansu Province on August 7, 2010, Journal of Engineering Geology, 18(4), 437-444, 2010 (in Chinese with English abstract). 